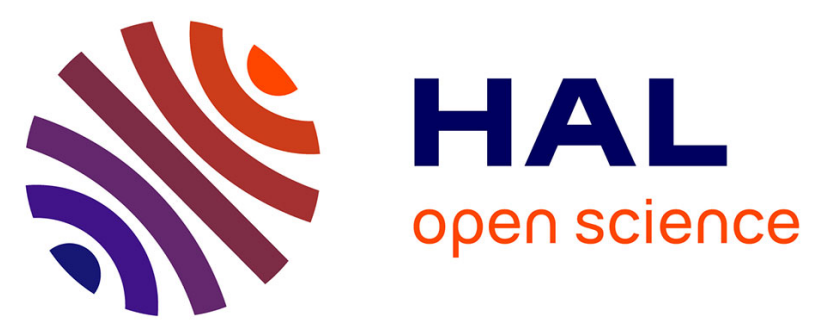

\title{
A simple biosynthetic method for stereospecific resonance assignment of prochiral methyl groups in proteins
}

Michael J Plevin, Olivier Hamelin, Jérôme Boisbouvier, Pierre Gans

\section{To cite this version:}

Michael J Plevin, Olivier Hamelin, Jérôme Boisbouvier, Pierre Gans. A simple biosynthetic method for stereospecific resonance assignment of prochiral methyl groups in proteins. Journal of Biomolecular NMR, 2011, 49 (2), pp.61-67. 10.1007/s10858-010-9463-3 . hal-01138581

\author{
HAL Id: hal-01138581 \\ https://hal.science/hal-01138581
}

Submitted on 21 Jun 2021

HAL is a multi-disciplinary open access archive for the deposit and dissemination of scientific research documents, whether they are published or not. The documents may come from teaching and research institutions in France or abroad, or from public or private research centers.
L'archive ouverte pluridisciplinaire HAL, est destinée au dépôt et à la diffusion de documents scientifiques de niveau recherche, publiés ou non, émanant des établissements d'enseignement et de recherche français ou étrangers, des laboratoires publics ou privés. 


\title{
A simple biosynthetic method for stereospecific resonance assignment of prochiral methyl groups in proteins
}

\author{
Michael J. Plevin • Olivier Hamelin • \\ Jérôme Boisbouvier · Pierre Gans
}

Received: 29 September 2010/ Accepted: 26 November 2010

(C) Springer Science+Business Media B.V. 2011

\begin{abstract}
A new method for stereospecific assignment of prochiral methyl groups in proteins is presented in which protein samples are produced using $\mathrm{U}-\left[{ }^{13} \mathrm{C}\right]$ glucose and subsaturating amounts of $2-\left[{ }^{13} \mathrm{C}\right]$ methyl-acetolactate. The resulting non-uniform labeling pattern allows pro $R$ and proS methyl groups to be easily distinguished by their different phases in a constant-time two-dimensional ${ }^{1} \mathrm{H}-{ }^{13} \mathrm{C}$ correlation spectra. Protein samples are conveniently prepared using the same media composition as the main uniformly-labeled sample and contain higher levels of isotopeenrichment than fractional labeling approaches. This new strategy thus represents an economically-attractive, robust alternative for obtaining isotopically-encoded stereospecific NMR assignments of prochiral methyl groups.
\end{abstract}

Keywords Isotope labeling - Stereospecific assignments . Acetolactate $\cdot$ Prochiral methyl groups

Electronic supplementary material The online version of this article (doi:10.1007/s10858-010-9463-3) contains supplementary material, which is available to authorized users.

M. J. Plevin · J. Boisbouvier · P. Gans

CEA, Institut de Biologie Structurale Jean-Pierre Ebel,

Grenoble, France

M. J. Plevin · J. Boisbouvier · P. Gans

CNRS, Institut de Biologie Structurale Jean-Pierre Ebel, Grenoble, France

M. J. Plevin $(\bowtie) \cdot$ J. Boisbouvier · P. Gans Institut de Biologie Structurale Jean-Pierre Ebel, Université Joseph Fourier, Grenoble, France

e-mail: michael.plevin@ibs.fr

O. Hamelin

CNRS, Laboratoire de Chimie et Biologie des Métaux,

17 avenue des martyrs, Grenoble, France

\section{Introduction}

NMR spectroscopy is a well-established technique for elucidating atomic resolution 3D structures of proteins. The final quality of an NMR-elucidated 3D structural ensemble is heavily dependent on a number of factors, including the accuracy and completeness of resonance assignments, and the number and type of structural constraints used. Interproton distances derived from NOE spectra remain the major source of information used in NMR structure calculations. The quality and precision of an NMR-elucidated structural ensemble can greatly benefit from correct assignment of resonances from prochiral groups (e.g. methylene protons, aromatic ring protons, isopropyl methyl groups, etc; Billeter et al. 1989; Driscoll et al. 1989; Güntert et al. 1989; Folmer et al. 1997; Kainosho et al. 2006). Perhaps the most important prochiral class in proteins comprises the methyl groups of Leu and Val residues which are often found in the hydrophobic core of proteins and form important long-range inter-residue contacts (Janin et al. 1988; Lo Conte et al. 1999; Tugarinov and Kay 2005). NOEs between methyl groups are therefore crucial for resolving the structure of the hydrophobic core of a protein. Stereospecific assignments can greatly improve the precision of NMR structures by allowing NOEs to be accurately assigned to specific methyl groups and thus avoiding the use of floating prochiral assignments or pseudo-atoms (Güntert et al. 1989).

The methyl groups in leucine (Leu) or valine (Val) side chains are useful sources of structural information. In general methyl groups have strong NMR signals due to proton multiplicity and rapid rotation around the 3-fold methyl symmetry axis, and consequently give rise to easily detected NOE crosspeaks (Tugarinov and Kay 2003). In the past 25 years several approaches have been developed 
to allow stereospecific assignment of the prochiral methyl groups of Leu and Val. Such methods have tended to be based on either (a) isotope-labeling (Neri et al. 1989; Ostler et al. 1993; Tate et al. 1995; Atreya and Chary 2001; Kainosho et al. 2006); (b) measurement of NMR parameters (Sattler et al. 1992; Vuister et al. 1993; Tang et al. 2005); or (c) computational prediction of prochirality from NMR data or structures (Pristovsek and Franzoni 2006). The most widely used approach to date involves fractional isotope labeling of the target protein. In this protocol the protein is expressed from a minimal culture medium containing $10 \%\left[{ }^{13} \mathrm{C}\right]$ glucose and $90 \%\left[{ }^{12} \mathrm{C}\right]$ glucose (Neri et al. 1989). The signals of prochiral methyl groups in the resulting protein can then be differentiated by their phase in a constant-time (CT) $2 \mathrm{D}^{1} \mathrm{H}_{-}-{ }^{13} \mathrm{C}$ correlated spectrum. This elegant and simple method has found great use for determining stereospecific assignments in small and large proteins alike (Tugarinov and Kay 2004; Yee et al. 2006) and has spawned subsequent variations (Atreya and Chary 2001), and specifically devised NMR experiments (Hu and Zuidereg 1996), as well aiding the assignment of other nuclei (e.g. Jacob et al. 2002). One of the main practical drawbacks is that fractional labeling requires an additional and separate expression and purification of the target protein. Due to the low level of isotope enrichment, and therefore reduced sensitivity in subsequent experimental analysis, a fractional labeling strategy often necessitates preparing culture volumes comparable to those required for the primary $\left[{ }^{13} \mathrm{C},{ }^{15} \mathrm{~N}\right]$-labeled samples used for resonance assignment and NOE analysis.

Here, a method is presented that allows simple and efficient spectroscopic-differentiation of prochiral methyl groups in proteins. This new strategy utilizes the stereospecific enzymatic reactions that occur in the early stages of Leu and Val biosynthesis in E. coli. The final protein sample contains a mixture of isotope-labeling at prochiral sites with partial uniform $\left[{ }^{13} \mathrm{C}\right]$-labeling of Leu and Val side chains and partial $\left[{ }^{13} \mathrm{C}^{1} \mathrm{H}_{3}\right]^{\text {pros }}$-specific labeling. This labeling pattern allows NMR signals of pro $R$ and proS methyl groups in the resulting protein to be distinguished by their sign in CT heteronuclear NMR spectra.

We recently reported the use of a metabolic intermediate in the biosynthesis pathway of Leu and Val, 2-hydroxy-2methyl-butanoate (or acetolactate), for stereospecific labeling of proS methyl groups in large proteins (Gans et al. 2010). The addition of $2-\left[{ }^{13} \mathrm{C}\right]$ methyl- $4\left[{ }^{2} \mathrm{H}_{3}\right]$-acetolactate to an $E$. coli expression culture produces a target protein with a Leu/Val- $\left[{ }^{13} \mathrm{C}^{1} \mathrm{H}_{3}\right]^{\text {proS }},\left[{ }^{12} \mathrm{C}^{2} \mathrm{H}_{3}\right]^{\text {proR }}$-labeling pattern. This labeling strategy is ideal for high molecular weight proteins, which require a high-level of background deuteration. U- $\left[{ }^{2} \mathrm{H},{ }^{13} \mathrm{C},{ }^{15} \mathrm{~N}\right]$-labeled proteins with specific Leu/ Val- $\left[{ }^{13} \mathrm{C}^{1} \mathrm{H}_{3}\right]^{\text {pros }}$-labeling can be conveniently prepared from a $\mathrm{D}_{2} \mathrm{O}$-based expression medium supplemented with
2- $\left[{ }^{13} \mathrm{C}\right]$ methyl-4 $\left[{ }^{2} \mathrm{H}_{3}\right]$-acetolactate and $\mathrm{U}-\left[{ }^{2} \mathrm{H},{ }^{13} \mathrm{C}\right]$ glucose. Acetolactate is thus an attractive alternative to using $\alpha$-ketoisovalerate (Goto et al. 1999; Lichtenecker et al. 2004; Tugarinov and Kay 2003). The main advantage in using acetolactate stems from the fact that $\alpha$-ketoisovalerate is only available as a racemic mixture and thus results in equal labeling of pro $R$ and proS methyl groups across the sample, although with only a single $\left[{ }^{1} \mathrm{H},{ }^{13} \mathrm{C}\right]$-labeled methyl group per residue (Tugarinov and Kay 2003).

In a $2 \mathrm{D} \mathrm{CT}{ }^{1} \mathrm{H},{ }^{13} \mathrm{C}$ heteronuclear NMR spectra of a uniformly $\left[{ }^{13} \mathrm{C}\right]$-labeled protein all methyl group resonances have the same phase and consequently prochiralspecific assignments of Leu/Val methyl groups can not be determined (Fig. 1a). However, it is possible to manipulate the labeling patterns of the side chains of Leu and Val by supplementing the expression medium with suitable metabolic precursor. Using $2-\left[{ }^{13} \mathrm{C}\right]$ methyl-acetolactate produces a labeling pattern in which the proS methyl group is $\left[{ }^{13} \mathrm{C}\right]$-labeled while the remainder of the side chain is $\left[{ }^{12} \mathrm{C}\right]$-labeled. As Leu-C ${ }^{\gamma}$ and Val- $\mathrm{C}^{\beta}$ sites are $\left[{ }^{12} \mathrm{C}\right]$-labeled the signal arising from a proS methyl group is not affected by the evolution of a ${ }^{1} J_{\mathrm{CC}}$ coupling during the $\mathrm{CT}$ period and thus the corresponding signals appear $180^{\circ}$ out of phase compared to the same signal in a uniformly $\left[{ }^{13} \mathrm{C}\right]-$ labeled sample (Fig. 1b).

Adding a saturating amount of $2-\left[{ }^{13} \mathrm{C}\right]$ methyl-acetolactate removes crosspeaks originating from pro $R$ methyl groups (ignoring the residual $\left[{ }^{13} \mathrm{C}\right]$-labeling derived from natural abundance). However, if a smaller, non-saturating amount of 2-[ $\left[{ }^{13} \mathrm{C}\right]$ methyl-acetolactate is used in addition to $\mathrm{U}-\left[{ }^{13} \mathrm{C}\right]$ glucose then both $\operatorname{pro} R$ and $\operatorname{pro} S$ resonances will be detected as, over the whole NMR sample, certain prochiral sites would be derived from glucose and others from 2- $\left[{ }^{13} \mathrm{C}\right]$ methyl-acetolactate (Fig. 1c). With this mixedlabeled sample the proS crosspeak observed is the sum of the opposite-phased glucose-derived and acetolactatederived $\operatorname{pro} S$ crosspeaks. The phase of the $\operatorname{pro} S$ peak can therefore be manipulated by changing the amount of $2-\left[{ }^{13} \mathrm{C}\right]$ methyl-acetolactate used. For example, if $66 \%$ of the metabolic pool of Leu and Val has been produced using 2- $\left[{ }^{13} \mathrm{C}\right]$ methyl-acetolactate then the glucose-derived proS signal would be completely cancelled out. This scenario would result in a spectrum in which the $\operatorname{pro} R$ and $\operatorname{pro} S$ crosspeaks appear $180^{\circ}$ out of phase (Fig. 1c). Furthermore, the pro $R$ and $\operatorname{pro} S$ crosspeaks would have equal intensity but at $33 \%$ of the signal intensity normally observed in spectra of a protein produced using $\mathrm{U}-\left[{ }^{13} \mathrm{C}\right]$ glucose alone.

Protein production for NMR assignment or NOE-based structural analysis commonly involves the expression of the target protein from several liters of $\mathrm{U}-\left[{ }^{13} \mathrm{C},{ }^{15} \mathrm{~N}\right]$-enriched minimal expression medium. This strategy is outlined in Fig. $2 \mathrm{a}$ and is essentially routine for the characterization 
(a) $\mathrm{U}-\left[{ }^{1} \mathrm{H},{ }^{13} \mathrm{C}\right] \mathrm{glucose}$

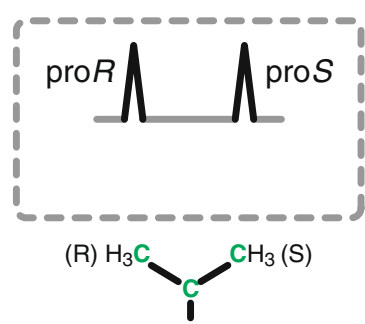

Fig. 1 Isotope-labeling patterns in prochiral methyl groups. a media containing $\mathrm{U}-\left[{ }^{13} \mathrm{C}\right]$ glucose as the sole carbon source produces proteins in which the side-chains of Leu and Val are uniformly $\left[{ }^{13} \mathrm{C}\right]$-labeled and consequently both methyl peaks have the same phase in a CT HSQC spectrum; b supplementing the expression medium with a saturating amount of $2-\left[{ }^{13} \mathrm{C}\right]$ methyl-acetolactate produces Leu and $\mathrm{Val}$ residues in which only the $\operatorname{proS}$ group is $\left[{ }^{13} \mathrm{C}\right]$ - (c) $\mathrm{U}-\left[{ }^{1} \mathrm{H},{ }^{13} \mathrm{C}\right] \mathrm{glucose}$

$66 \% 2-\left[{ }^{13} \mathrm{C}\right]$ methyl-acetolactate

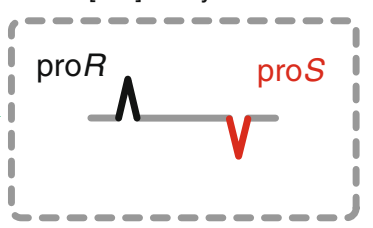

(a)

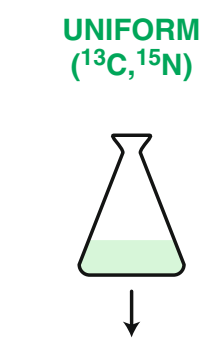

$\mathrm{U}-\left[{ }^{13} \mathrm{C},{ }^{15} \mathrm{~N}\right]$ protein

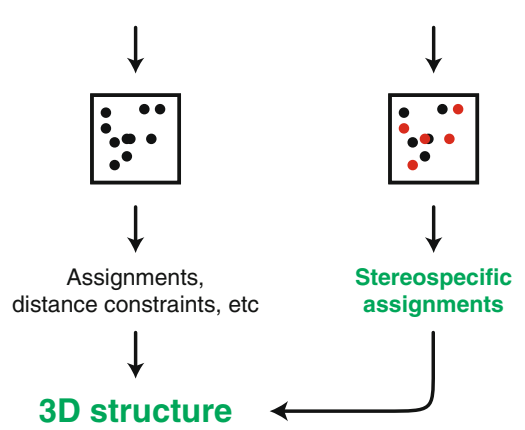

(b)

FRACTIONAL $\left({ }^{12} \mathrm{C} /{ }^{13} \mathrm{C}\right)$

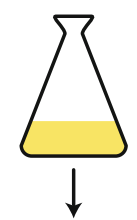

Fractionally labeled $\left[{ }^{12} \mathrm{C} /{ }^{13} \mathrm{C}\right]$ protein

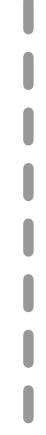

labeled, regardless of whether the glucose used was $\left[{ }^{13} \mathrm{C}\right]$-labeled or not. The proS crosspeak would appear $180^{\circ}$ out of phase to those in (a). c using sub saturating amounts $2-\left[{ }^{13} \mathrm{C}\right]$ methyl-acetolactate in addition to $\mathrm{U}-\left[{ }^{13} \mathrm{C}\right]$ glucose results in a protein sample with a mixture of labeling patterns for Leu and Val side-chains. In a CT HSQC spectrum of such a sample the pro $R$ and pro $S$ crosspeaks appear $180^{\circ}$ out of phase

(c)

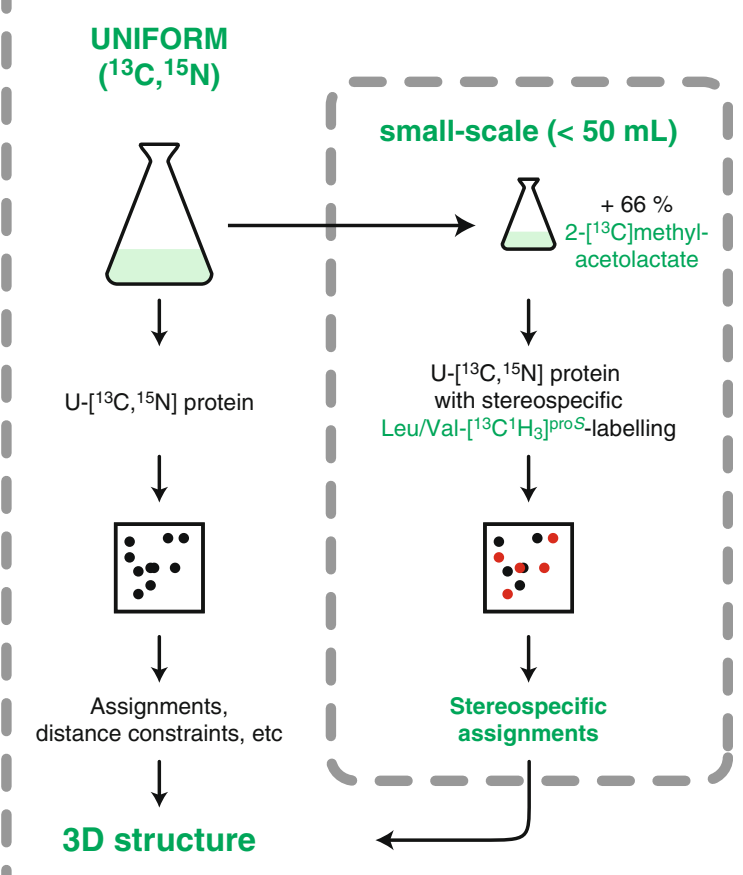

Fig. 2 Production of isotope-labeled samples for analysis by NMR spectroscopy. a an example of standard large-scale protocol for the production of $\mathrm{U}-\left[{ }^{13} \mathrm{C},{ }^{15} \mathrm{~N}\right]$-labeled proteins. Proteins are expressed from a uniformly $\left[{ }^{13} \mathrm{C},{ }^{15} \mathrm{~N}\right]$-labeled expression medium. This sample is ideal for backbone and side chain assignment and the acquisition of structural restraints, but it cannot be easily used for determining stereospecific assignments of prochiral methyl groups. b A fractional labeling approach can be used to establish stereospecific resonance assignments of prochiral methyl groups. In this instance the protein is expressed from a large-scale culture medium containing only $10 \%$ $\left[{ }^{13} \mathrm{C}\right]$ glucose and $90 \%\left[{ }^{12} \mathrm{C}\right]$ glucose. In a CT HSQC spectra recorded of this sample the crosspeaks of pro $R$ and pro $S$ methyl groups will be

of smaller proteins (e.g. $<25 \mathrm{kD}$ ). To obtain stereospecific assignments using a fractionally-labeled sample (e.g. with 5 or $10 \%\left[{ }^{13} \mathrm{C}\right]$-labeling) requires a separate round of $180^{\circ}$ out of phase. These stereospecific assignments can then be included in subsequent structural analyses. c Obtaining stereospecific assignments using $2-\left[{ }^{13} \mathrm{C}\right]$ methyl-acetolactate and a standard uniformly $\left[{ }^{13} \mathrm{C},{ }^{15} \mathrm{~N}\right]$-labeled expression medium. A small aliquot $(4-50 \mathrm{~mL})$ of the primary expression culture is taken at an optical density of $0.7 .2-\left[{ }^{13} \mathrm{C}\right]$ methyl-acetolactate is added at sub-saturating levels (the amount added is dependent on the amount of glucose used-see main text) and protein expression is induced 1 hour later (Gans et al. 2010). In a CT HSQC spectra recorded of this sample the crosspeaks of $\operatorname{pro} R$ and $\operatorname{pro} S$ methyl groups will be $180^{\circ}$ out of phase. These stereospecific assignments can then be included in subsequent structural analyses

protein expression using a specially prepared expression medium containing a different isotope composition (Fig. 2b; Neri et al. 1989). 
The availability of acetolactate means that an alternative protein production strategy for isotope-encoded differentiation of prochiral methyl group crosspeaks can be proposed. As outlined above, it is possible to supplement acetolactate to a glucose-containing medium at level that suppresses the glucose-derived proS signal but retains the pro $R$ signal. This labeling pattern would give a final effective level of isotope labeling of approximately 33\%, which is significantly higher than the $5-10 \%$ obtained using a fractional labeling protocol. As a sample produced using acetolactate has a higher effective concentration less sample is required for NMR analysis and consequently sufficient protein can be obtained from a much smaller volume of culture. Furthermore, acetolactate can be added to a uniformly-labeled culture medium. These two factors allow a new expression protocol to be proposed (Fig. 2c) in which a small aliquot $(<50 \mathrm{~mL})$ is taken from the primary $\mathrm{U}-\left[{ }^{13} \mathrm{C},{ }^{15} \mathrm{~N}\right]$-labeled expression culture to which a sufficient amount of $2-\left[{ }^{13} \mathrm{C}\right]$ methyl-acetolactate is added to ensure that approximately $66 \%$ the metabolic reservoir of Leu and Val is derived directly from the precursor. Protein expression is induced 1 hour later. As outlined in Fig. 1c, a CT HSQC spectrum of a protein produced in this way will still contain all the information that would be available using a U- $\left[{ }^{13} \mathrm{C},{ }^{15} \mathrm{~N}\right]$-labeled sample. However, the crosspeaks originating from proS methyl groups would be inverted with respect to the corresponding signal from a uniformly labeled sample.

The implementation of this approach in protonated expression media required a slight modification of the published synthesis scheme for acetolactate. The previously reported protocol produces 2-[ $\left[{ }^{13} \mathrm{C}\right]$ methyl- $4\left[{ }^{2} \mathrm{H}_{3}\right]$-acetolactate (Gans et al. 2010). This molecule is optimal for studying larger molecular systems as deuteration of the pro $R$ methyl group reduces the inter-methyl group dipolar interaction (Tugarinov and Kay 2003; Gans et al. 2010). When using protonated glucose to produce a uniformly protonated sample (e.g. using the protocol outlined in Fig. 2) it is necessary that the pro $R$ methyl group and directly bonded carbon (i.e. Leu- $\mathrm{C}^{\gamma}$ or $\mathrm{Val}-\mathrm{C}^{\beta}$ ) is protonated as this ensures that the signal of the $\operatorname{pro} S$ group produced on adding $2-\left[{ }^{13} \mathrm{C}\right]$ methyl-acetolactate has an identical chemical shift and linewidth to that produced from uniform $\left[{ }^{13} \mathrm{C}\right]$-labeling with glucose. Thus, $2-\left[{ }^{13} \mathrm{C}\right]$ methyl acetolactate was prepared by deprotection of ethyl 2-hydroxy, $2\left[{ }^{13} \mathrm{C}\right]$ methyl-3oxobutanoate in $\mathrm{H}_{2} \mathrm{O}$ at $\mathrm{pH} 13.0$ using the conditions previously described (Gans et al. 2010). Using fully-protonated $2-\left[{ }^{13} \mathrm{C}\right]$ methyl acetolactate instead of 2- $\left[{ }^{13} \mathrm{C}\right]$ methyl- $4\left[{ }^{2} \mathrm{H}_{3}\right]-$ acetolactate resulted in spectra in which the acetolactatederived crosspeaks overlapped perfectly with their glucosederived counterparts.

This new labeling approach for determining stereospecific assignments of Leu and Val methyl groups was tested on three proteins: ubiquitin $(8 \mathrm{kD})$, a T50V mutation of the CAP-Glycine domain of the $150^{\text {Glued }}$ subunit of dynactin ( $8 \mathrm{kD}$; Plevin et al. 2008) and YajG, (20 kD; Boudet et al. 2007). Each target protein was prepared from a small volume culture of $\left[{ }^{13} \mathrm{C},{ }^{15} \mathrm{~N}\right]$-labeled minimal medium. The volume used was dependent on the expression level of the target protein and typically between 4 and $50 \mathrm{~mL}$. Each culture was supplemented with $2-\left[{ }^{13} \mathrm{C}\right]$ methyl-acetolactate when the optical density at $600 \mathrm{~nm}\left(\mathrm{OD}_{600}\right)$ reached 0.7 . Protein expression was induced one hour later using IPTG (Gans et al. 2010). In each instance the protocol for cell growth and protein expression was identical to that employed for the preparation of a $\mathrm{U}-\left[{ }^{13} \mathrm{C},{ }^{15} \mathrm{~N}\right]$-labeled sample, up to the addition of $2-\left[{ }^{13} \mathrm{C}\right]$ methyl-acetolactate. Following protein expression each sample was purified in a single step using immobilized-nickel affinity chromatography. Eluted samples were then concentrated to $0.5 \mathrm{~mL}$ before undergoing 3-4 rounds of buffer exchange by ultrafiltration. The final protein concentrations used for NMR analysis were between 50 and $200 \mu \mathrm{M}$.

$\mathrm{CT}{ }^{1} \mathrm{H}_{-}{ }^{13} \mathrm{C}$ HSQC spectra were recorded of each protein using an unmodified pulse sequence from the BioPack library (Varian) with the CT period set to $27 \mathrm{~ms}$. Fig. 3 shows examples of $2 \mathrm{D}$ spectra recorded of $\mathrm{U}-\left[{ }^{13} \mathrm{C},{ }^{15} \mathrm{~N}\right]$ labeled samples using $\mathrm{U}-\left[{ }^{13} \mathrm{C}\right]$ glucose alone and those prepared using $\mathrm{U}-\left[{ }^{13} \mathrm{C}\right]$ glucose and $2-\left[{ }^{13} \mathrm{C}\right]$ methyl-acetolactate. As predicted from Fig. 1C, a subsection of crosspeaks in spectra recorded of samples expressed in the presence of 2-[ $\left[{ }^{13} \mathrm{C}\right]$ methyl-acetolactate change phase (Fig. 3). Plotting the negative and positive crosspeaks in different spectra unambiguously differentiates the two classes of prochiral methyl groups and easily allows stereospecific assignments to be made (Fig. 4).

The amount of acetolactate required to achieve perfect cancellation of glucose-derived proS crosspeaks is dependent on the amount of glucose used in the expression medium. $50-100 \mathrm{mg} / \mathrm{L}$ of $2-\left[{ }^{13} \mathrm{C}\right]$ methyl-acetolactate was found to be sufficient for media containing $2 \mathrm{~g} / \mathrm{L}\left[{ }^{13} \mathrm{C}\right]$ glucose (Figs. 3, 4 and Supplementary Figure 1) while the amount $2-\left[{ }^{13} \mathrm{C}\right]$ methyl-acetolactate required increased to $180-220 \mathrm{mg} / \mathrm{L}$ when using $3 \mathrm{~g} / \mathrm{L}$ glucose (Supplementary Figure 1). There exists the possibility of minor culture-byculture variations in the uptake and/or incorporation of the precursor, however the results presented here (Figs. 3, 4 and Supplementary Figure 1) demonstrate that our new approach is sufficiently robust to tolerate these differences.

The overall net level of isotope labeling in the final sample is $100 \%$ and approximately $33 \%$ for non-prochiral and prochiral methyl sites, respectively, which allows a 2D CT HSQC spectrum of sufficient intensity and resolution to be collected in less than one hour, depending on the sample concentration. To achieve the same level of sensitivity with a sample prepared using the fractional-labeling approach 
(a)

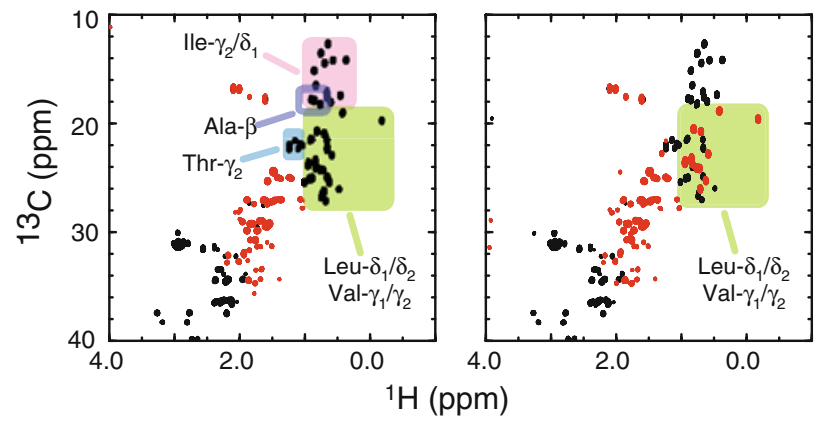

(c)

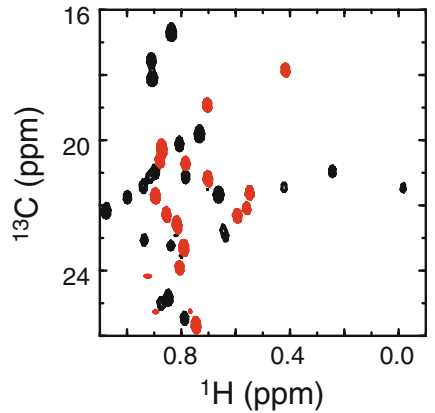

Fig. 3 Examples of 2D CT HSQC spectra of proteins prepared in the absence (a) and presence (b, c) of 2-[ $\left.{ }^{13} \mathrm{C}\right]$ methyl-acetolactate (positive contours, black; negative contours, red). All protein samples were prepared using $2 \mathrm{~g} / \mathrm{L} \quad \mathrm{U}-\left[{ }^{13} \mathrm{C}\right]$ glucose using small-scale $(<50 \mathrm{~mL})$ expression cultures. Spectra are presented for ubiquitin (a, b) and the CAP-Gly domain of the $150^{\text {Glued }}$ subunit of dynactin (c). The boxes in (a) indicate the resonance frequencies for each type of methyl group. The only crosspeaks to change sign in spectra of proteins prepared using $2-\left[{ }^{13} \mathrm{C}\right]$ methyl-acetolactate (supplemented at
$50-100 \mathrm{mg} / \mathrm{L}$ ) are those from the region containing the methyl groups of Leu and Val. NMR data were collected using an $800 \mathrm{MHz}$ Varian Direct Drive spectrometer equipped with pulsed-field gradients and a cryogenically-cooled triple resonance probe head. CT HSQC spectra were recorded with $(\mathbf{a}, \mathbf{b}) 256\left(t_{1}\right) \times 640\left(t_{2}\right)$ complex points and acquisition times of $21 \mathrm{~ms}\left(t_{1}\right)$ and $64 \mathrm{~ms}\left(t_{2}\right)$; or $(\mathbf{c}) 256\left(t_{1}\right) \times 1,048$ $\left(t_{2}\right)$ complex points and acquisition times of $16 \mathrm{~ms}\left(t_{1}\right)$ and $78 \mathrm{~ms}\left(t_{2}\right)$. 16 scans were collected per indirect increment with the CT delay set to $27 \mathrm{~ms}$ (a)

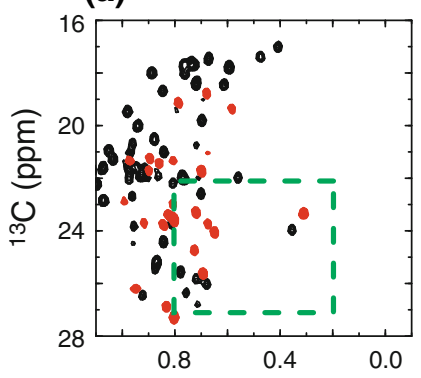

(b)

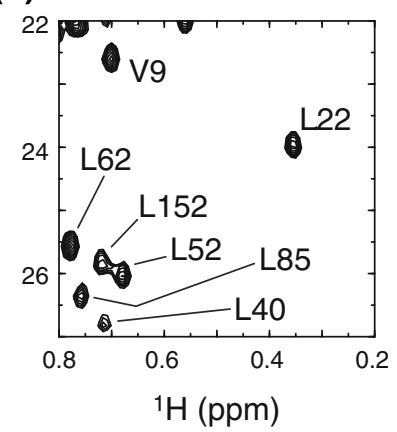

(c)

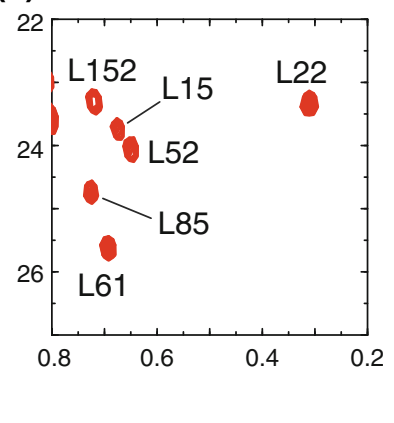

Fig. 4 Stereospecific assignment of Leu and Val methyl resonances. (a) region of the CT HSQC spectrum of YajG (positive contours, black; negative contours, red); Assignments for crosspeaks within the green box in (a) are provided in two sub spectra showing either the positive (b) or negative (c) contours of (a). pro $R$ methyl groups yield positive signals (b) while pro $S$ groups yield negative signals (c).

would require either 3-4 times as much protein (Supplementary Figure 2) or 9-16 times more spectrometer time.

It was recently reported that acetolactate derivatives for isotope-labeling of protein samples are commercially available (Ruschak et al. 2010). The data presented in Figs. 3 and 4 was obtained from protein samples prepared

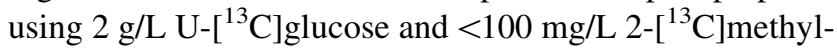
acetolactate. For a small scale culture (e.g. $50 \mathrm{~mL}$ ) the total isotope consumption is only $0.1 \mathrm{~g} \mathrm{U}-\left[{ }^{13} \mathrm{C}\right]$ glucose and $\sim 5$ mg 2-[ $\left.{ }^{13} \mathrm{C}\right]$ methyl-acetolactate. The additional cost of supplementing a $50 \mathrm{~mL}$ expression media with a subsaturating amount of $2-\left[{ }^{13} \mathrm{C}\right]$ methyl-acetolactate would be less than $\$ 10$.

Most importantly, the background isotope labeling scheme of the expression medium (e.g. U- $\left[{ }^{13} \mathrm{C}\right]$ glucose,
NMR data were collected using an $800 \mathrm{MHz}$ Varian Direct Drive spectrometer equipped with pulsed-field gradients and a cryogenically-cooled triple resonance probe head. CT HSQC spectra were recorded with $256\left(t_{1}\right) \times 1,048\left(t_{2}\right)$ complex points, acquisition times of $16 \mathrm{~ms}\left(t_{1}\right)$ and $78 \mathrm{~ms}\left(t_{2}\right)$ and 16 scans per indirect increment. The CT delay set to $27 \mathrm{~ms}$

$\left.\mathrm{U}-\left[{ }^{15} \mathrm{~N}\right] \mathrm{NH}_{4} \mathrm{Cl}\right)$ is identical to that used in the preparation of the main uniformly-labeled sample used for resonance assignment and NOESY data collection. This means that, using the protocol detailed here, it is not necessary to produce multiple large-scale cultures with different isotope enrichment schemes. As outlined in Fig. 2c, it is sufficient to take a small aliquot of the main culture and use this to prepare protein samples for prochiral methyl group assignment in parallel.

One of the advantages of expressing stereospecifically labeled samples from a standard uniformly-labeled expression media is that the changes to the resulting CT HSQC spectra are limited to the prochiral methyl groups (Figs. 2a, b). This is not the case for fractionally labeled samples (Supplementary Fig. 2c) where additional changes 
in the spectrum are observed, such as the disappearance of Ile- $\delta_{1}$ methyl resonances and the decreases in signal intensity of crosspeaks of Thr- $\gamma_{1}$ methyl groups which could potentially overlap with Leu or Val prochiral methyl peaks.

For larger proteins or for spectra with considerable overlap of methyl resonances, removing crosspeaks associated with pro $R$ methyl groups may greatly ease the process of resonance assignment. This can easily be achieved by increasing the amount of $2-\left[{ }^{13} \mathrm{C}\right]$ methyl-acetolactate used. Supplementing the expression media with saturating levels of acetolactate would cause complete suppression of proR peaks and thus decrease spectral crowding (Supplementary Figure 1).

In conclusion, the isotope-labeling strategy outlined here is a simple yet robust method for producing a protein in which the stereospecific assignment of prochiral resonances are isotopically pre-encoded. This new approach benefits from an improved level of isotope-enrichment and the fact that stereospecific assignments can be obtained from a 2D CT-HSQC. Both of these factors considerably decrease the amount of protein required and the time needed for protein production, as well as reducing spectrometer and analysis time. Consequently, the small extra isotope expense incurred using $2-\left[{ }^{13} \mathrm{C}\right]$ methyl-acetolactate is very easily offset by the reduction in spectrometer costs and more efficient use of human resources. This new protocol therefore represents a widely-applicable, straightforward, cost-effective and reliable method for obtaining stereospecific assignments of prochiral methyl groups.

Acknowledgements The authors wish to thank Drs S. Grzesiek, I. Hayashi and J.-P. Simorre for the donation of plasmids, members of the NMR laboratory at the IBS, Grenoble for critical reading of the manuscript, and the Partnership for Structural Biology, Grenoble for access to integrated structural biology platforms. M.J.P. acknowledges funding from L'Association pour la Recherche sur le Cancer and the European Union (FP7-PEOPLE-IRG-2008). This work was partially funded from a grant awarded by l'Agence Nationale de la Recherche to J.B. and O.H., ANR PIRIB.009/445583).

\section{References}

Atreya HS, Chary KV (2001) Selective 'unlabeling' of amino acids in fractionally ${ }^{13} \mathrm{C}$ labeled proteins: an approach for stereospecific NMR assignments of $\mathrm{CH}_{3}$ groups in Val and Leu residues. J Biomol NMR 19:267-272

Billeter M, Kline AD, Braun W, Huber R, Wuthrich K (1989) Comparison of the high-resolution structures of the alphaamylase inhibitor tendamistat determined by nuclear magnetic resonance in solution and by X-ray diffraction in single crystals. J Mol Biol 206:677-687

Boudet J, Chouquet A, Chahboune A, Giustini C, Joris B, Simorre JP, Bougault $\mathrm{C}(2007){ }^{1} \mathrm{H},{ }^{13} \mathrm{C}$ and ${ }^{15} \mathrm{~N}$ resonance assignments of
YajG, an Escherichia coli protein of unknown structure and function. Biomol NMR Assign 1:89-91

Driscoll PC, Gronenborn AM, Clore GM (1989) The influence of stereospecific assignments on the determination of three-dimensional structures of proteins by nuclear magnetic resonance spectroscopy. Application to the sea anemone protein BDS-I. FEBS Lett 243:223-233

Folmer RH, Hilbers CW, Konings RN, Nilges M (1997) Floating stereospecific assignment revisited: application to an $18 \mathrm{kDa}$ protein and comparison with $J$-coupling data. J Biomol NMR 9:245-258

Gans P, Hamelin O, Sounier R, Ayala I, Dura MA, Franzetti B, Plevin MJ, Boisbouvier J (2010) Stereospecific isotopic labeling of methyl groups for the NMR studies of high molecular weight proteins. Angew Chem Int Ed Engl 49:1958-1962

Goto NK, Gardner KH, Mueller GA, Willis RC, Kay LE (1999) A robust and cost-effective method for the production of Val, Leu, Ile (delta 1) methyl-protonated ${ }^{15} \mathrm{~N}-,{ }^{13} \mathrm{C}-,{ }^{2} \mathrm{H}$-labeled proteins. J Biomol NMR 13:369-374

Güntert P, Braun W, Billeter M, Wüthrich K (1989) Automated stereospecific proton NMR assignments and their impact on the precision of protein structure determinations in solution. J Am Chem Soc 111:3997-4004

$\mathrm{Hu}$ W, Zuidereg ERP (1996) Stereospecific assignments of Val and Leu methyl groups in a selectively ${ }^{13} \mathrm{C}$-labeled $18 \mathrm{kDa}$ polypeptide using 3D CT-(H)CCH-COSY and $2 \mathrm{D}{ }^{1} J_{\mathrm{C}-\mathrm{C}}$ edited heteronuclear correlation experiments. J Mag Res B 113:70-75

Jacob J, Louis JM, Nesheiwat I, Torchia DA (2002) Biosynthetically directed fractional ${ }^{13} \mathrm{C}$ labeling facilitates identification of Phe and Tyr aromatic signals in proteins. J Biomol NMR 24:231-235

Janin J, Miller S, Chothia C (1988) Surface, subunit interfaces and interior of oligomeric proteins. J Mol Biol 204:155-164

Kainosho M, Torizawa T, Iwashita Y, Terauchi T, Mei Ono A, Guntert P (2006) Optimal isotope labelling for NMR protein structure determinations. Nature 440:52-57

Lichtenecker R, Ludwiczek ML, Schmid W, Konrat R (2004) Simplification of protein NOESY spectra using bioorganic precursor synthesis and NMR spectral editing. J Am Chem Soc 126:5348-5349

Lo Conte L, Chothia C, Janin J (1999) The atomic structure of protein-protein recognition sites. J Mol Biol 285:2177-2198

Neri D, Szyperski T, Otting G, Senn H, Wuthrich K (1989) Stereospecific nuclear magnetic resonance assignments of the methyl groups of valine and leucine in the DNA-binding domain of the 434 repressor by biosynthetically directed fractional ${ }^{13} \mathrm{C}$ labeling. Biochemistry 28:7510-7516

Ostler G, Soteriou A, Moody CM, Khan JA, Birdsall B, Carr MD, Young DW, Feeney J (1993) Stereospecific assignments of the leucine methyl resonances in the ${ }^{1} \mathrm{H}$ NMR spectrum of Lactobacillus casei dihydrofolate reductase. FEBS Lett 318:177-180

Plevin MJ, Hayashi I, Ikura M (2008) Characterization of a conserved "threonine clasp" in CAP-Gly domains: role of a functionally critical $\mathrm{OH} / \pi$ interaction in protein recognition. J Am Chem Soc 130:14918-14919

Pristovsek P, Franzoni L (2006) Stereospecific assignments of protein NMR resonances based on the tertiary structure and 2D/3D NOE data. J Biomol NMR 27:791-797

Ruschak AM, Velyvis A, Kay LE (2010) Stereospecific assignment of leucine methyl groups with carbon-13 in natural abundance or with random ${ }^{13} \mathrm{C}$ labeling. J Biomol NMR 48:129-135

Sattler M, Schwalbe H, Griesinger C (1992) Stereospecific assignment of leucine methyl groups with carbon-13 in natural abundance or with random ${ }^{13} \mathrm{C}$ labeling. J Am Chem Soc 114:1126-1127 
Tang C, Iwahara J, Clore GM (2005) Accurate determination of leucine and valine side-chain conformations using $\mathrm{U}-\left[{ }^{15} \mathrm{~N} /{ }^{13} \mathrm{C} /{ }^{2} \mathrm{H}\right] /$ $\left[{ }^{1} \mathrm{H}\right.$-(methine/methyl)-Leu/Val] isotope labeling, NOE pattern recognition, and methine $\mathrm{C}_{\gamma}-\mathrm{H}_{\gamma} / \mathrm{C}_{\beta}-\mathrm{H}_{\beta}$ residual dipolar couplings: application to the $34 \mathrm{kDa}$ enzyme IIA(chitobiose). J Biomol NMR 33:105-121

Tate S, Ushioda T, Utsunomiya-Tate N, Shibuya K, Ohyama Y, Nakano Y, Kaji H, Inagaki F, Samejima T, Kainosho M (1995) Solution structure of a human cystatin A variant, cystatin A2-98 M65L, by NMR spectroscopy. A possible role of the interactions between the $\mathrm{N}$ - and $\mathrm{C}$-termini to maintain the inhibitory active form of cystatin. Biochemistry 34:14637-14648

Tugarinov V, Kay LE (2003) Ile, Leu, and Val methyl assignments of the 723-residue malate synthase $\mathrm{G}$ using a new labeling strategy and novel NMR methods. J Am Chem Soc 125:13868-13878
Tugarinov V, Kay LE (2004) Stereospecific NMR assignments of prochiral methyls, rotameric states and dynamics of valine residues in malate synthase. J Am Chem Soc 126:9827-9836

Tugarinov V, Kay LE (2005) Methyl groups as probes of structure and dynamics in NMR studies of high-molecular-weight proteins. Chem biochem 6:1567-1577

Vuister GW, Yamazaki T, Torchia DA, Bax A (1993) Measurement of two- and three-bond ${ }^{13} \mathrm{C}-{ }^{1} \mathrm{H} J$-couplings to the $\mathrm{C}$ delta carbons of leucine residues in staphylococcal nuclease. J Biomol NMR 3:297-306

Yee A, Gutmanas A, Arrowsmith CH (2006) Solution NMR in structural genomics. Curr Opin Struct Biol 16:611-617 